\title{
Hertug Ernst Günther og jernbanen til Gråsten
}

\author{
af LARS H. BAK
}

I 1899 nåede Aabenraa amts jernbaner frem til Gråsten. I 1901 kom også statsbanen til byen. Forud og efterfølgende gik langvarige forhandlinger mellem hertug Ernst Günther i Gråsten og statslige og kommunale myndigheder. Sagsforløbet er interessant - for hertugen var ikke hvemsomhelst. Ernst Günther var svoger til kejser Wilhelm II. Samtidig er sagsforløbene et eksempel på de problemer der kunne opstå, når grundejere fik deres ejendom gennemskåret af jernbaneanlæg - en overset problemstilling $\mathrm{i}$ den ellers righoldige jernbanelitteratur. I artiklen her belyser historiestuderende Lars H. Bak, Århus, tidl. Sønderborg, hvorvidt hertugens fremtrædende stilling gav anledning til særbehandling

Tager man toget fra Sønderborg ad den godt 100 år gamle jernbanestrækning til Tinglev, kører man kort før banegården i Gråsten gennem det tidligere Gråsten godsdistrikt. Godsdistriktets sidste ejer var hertug Ernst Günther zu Schleswig-Holstein (1863-1921), der var den sidste repræsentant for den augustenborgske hertugslægt i Nordslesvig. Godsdistriktet bestod af de bortforpagtede herregårde Gråsten Ladegård og Fiskbæk nord for Gråsten samt Gråsten Slot, hvor hertug Ernst Günther ofte opholdt sig i sommer- og jagtsæsonen. Til daglig boede han på godset Primkenau i Niederschlesien, hvor den hertugelige generaldirektion havde sit hovedsæde.

Omkring forrige århundredeskifte blev Gråsten godsdistrikt gennemskåret af såvel statsbanen til Sønderborg, som den i 1926 nedlagte kredsbane fra Aabenraa til Gråsten. Banerne var resultatet af årtiers jernbanedebatter, der havde Sønderborgs forbindelse med det øvrige jernbanenet som udgangspunkt. Debatterne havde i øvrigt rødder tilbage til 1844, hvor ingen ringere end hertug Christian August, Ernst Günthers farfar, foreslog en jernbane fra Flensborg over Sønderborg til Fynshav. Hertug Ernst Günther selv synes derimod ikke at have deltaget $\mathrm{i}$ debatterne.

Om hertug Ernst Günthers virke omkring Gråsten er der ikke skrevet meget. Næsten ukendt er således, at grunderhvervelserne til såvel 
statsbanen som kredsbanen forårsagede årelange sagsforløb mellem hertugen på den ene side og de preussiske statsbaner repræsenteret ved "Königliche Eisenbahndirektion zu Altona", KED-Altona, og Kreis Apenrade, der ejede kredsbanen, på den anden side. Dertil kommer et par andre jernbanesager, som hertugen og godsdistriktet var involveret i. På grundlag af studier i især Aabenraa Amts Jernbaners (Aa.A.J.) arkiv og i de arkivalier, som KED-Altona afleverede til DSB i 1921, søges disse sagsforløb klarlagt i artiklen her.

Udover at fremdrage en række lokalhistoriske detaljer giver sagsforløbene et billede af hertug Ernst Günthers stilling i forhold til den offentlige administration. Nok havde hertug Ernst Günther i 1884 givet afkald på alle rettigheder til hertugdømmerne, men via søsteren Auguste Victoria var hertugen svoger til kejser Wilhelm II. I 1895 havde kejseren udnævnt hertug Ernst Günther til arveligt medlem af det preussiske overhus »Herrenhaus«. Omstændigheder som måske nok kunne give hertugen en vis anseelse. Men havde disse forhold også indflydelse på de preussiske myndigheders behandling af de her fremdragne sagsforløb?

\section{Grunderhvervelserne til kredsbanen}

I midten af 1890erne nåede de langvarige jernbanedebatter til en afklaring. Således vedtog kredsdagen i Aabenraa den 25. september 1896 anlægget af en kredssmåbane fra Aabenraa over Felsted-VarnæsBovrup til Gråsten. Kredsbanen blev vedtaget og anlagt i henhold til bestemmelserne i den preussiske »Kleinbahngesetz « af 28. juli 1892, der stillede en række lempeligere krav til disse småbaner, der var baner af udelukkende lokal betydning, i modsætning til de øvrige jernbaner, der anlagdes efter de strengere bestemmelser i bl.a. jernbaneloven af 3. november 1838. Kredsbanen Aabenraa-Gråsten anlagdes smalsporet med $1000 \mathrm{~mm}$ sporvidde og blev projekteret af Emil Hyronimus Kuhrt (1848-1909), der bl.a. var driftsdirektør for FlensborgKappel kredsbanen, ligesom Kuhrt undervejs overtog ledelsen af anlægsarbejdet og var den første driftsdirektør for kredsbanerne i Aabenraa. Den øverste ledelse af kredsbanerne på kredsens vegne var kredsjernbanekommissionen, der valgtes af kredsdagen. I Aabenraa kreds var der endog som regel to dansksindede medlemmer. Formanden for kommissionen var landråden, der som formand for også kredsdagen og kredsens udøvende myndighed kredsudvalget var en 


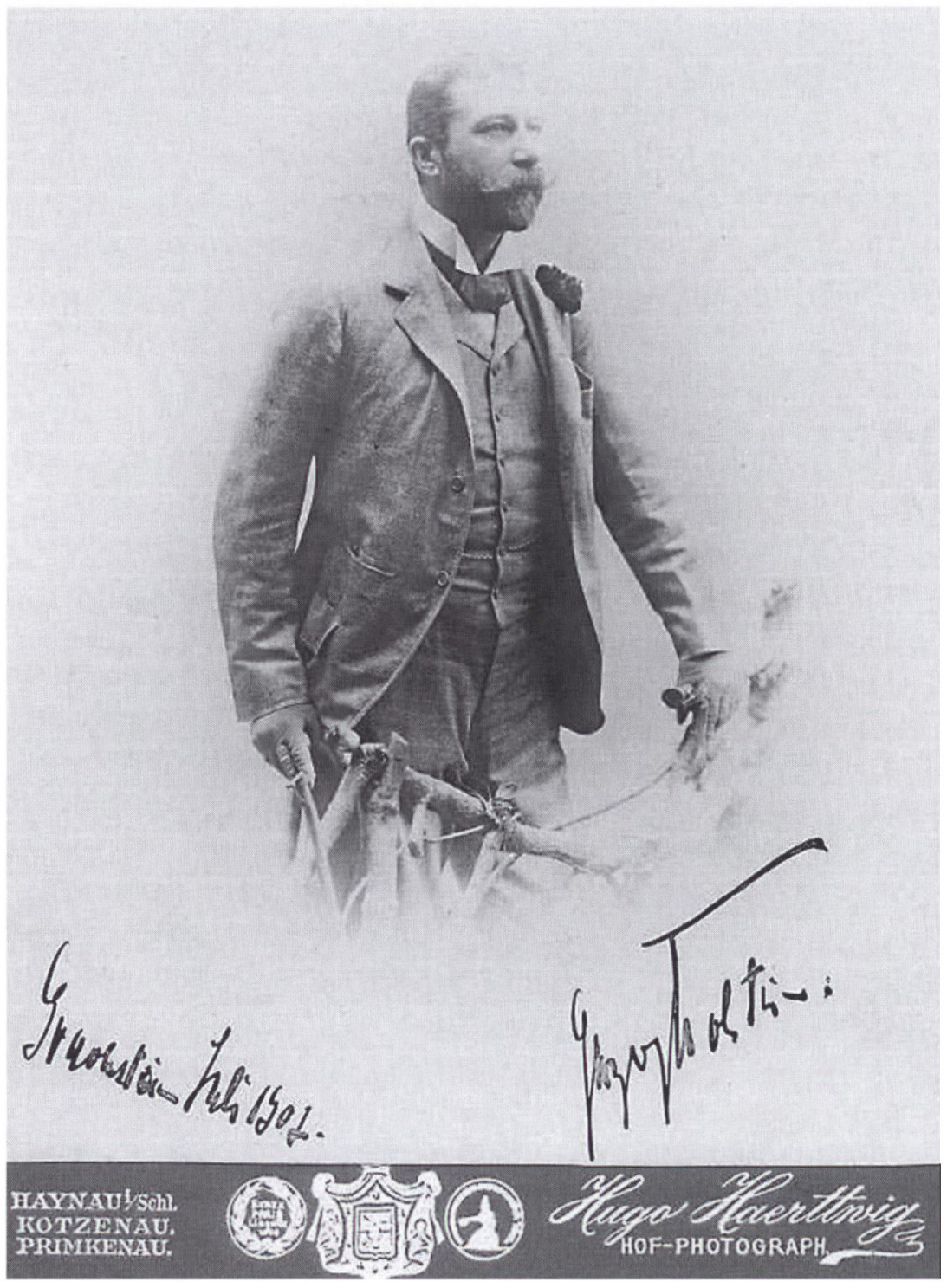

Hertug Ernst Günther (1863-1921). Hertugens ægteskab med Dorothea af SachsenCoburg-Gotha (1881-1967) var barnløst, og han blev reelt den sidste repræsentant for den augustenborgske hertugslægt $i$ Nordslesvig. Efter forhandlinger indledt allerede før Ernst Günthers pludselige død afstod enkehertuginde Dorothea slottene $i$ Augustenborg, Sønderborg og Gråsten til den danske stat $i$ 1921. Foto: Museet på Sønderborg Slot. 
central person i lokale jernbanesager. Landråden i Aabenraa kreds i det meste af den her omhandlede periode var den navnkundige Rafael José Perfecto Antonio von Uslar, der var landråd 1895-1913. ${ }^{1}$

\section{De første forhandlinger}

I oktober 1896 indledte kredsjernbanekommissionen forhandlinger med de berørte grundejere om afståelse af grunde til kredsbanen. Den 15. oktober forhandledes på Gråsten godsdistrikt. Repræsentant for hertug Ernst Günther var »herzogliche Rentmeister « F. Lenschau (1841-1910), der udover at være hertugens mand i Gråsten som amtsforstander også var lokal politimyndighed. Ved forhandlingerne erklærede Lenschau sig villig til, for så vidt som han var berettiget, at afstå de nødvendige arealer til kredsbanen. For en påtænkt byggeplads ved Friedrichstrasse (nuv. Nygade) skulle ydes en erstatning på $3.000 \mathrm{M}$ og ved skoven Overstjernen skulle et sidespor anlægges af kredsbanen. $^{2}$

Fra senere sagsakter vides, at der ved forhandlingerne fremlagdes et kort over den planlagte linieføring, hvor den påtænkte statsbane også var indtegnet. Kredsbanen skulle kort efter holdepladsen Fiskbæk Skov i vest føres $i$ østlig og senere sydøstlig retning ind over godsdistriktet og frem til holdepladsen ved herregården Fiskbæk og videre frem til Flensborgchausseen fra Gråsten til Sønderborg vest for Adsbøl. Kort efter skæringen med denne skulle kredsbanen forløbe parallelt med den vedtagne statsbane forbi og igennem skovene Overstjernen og Nederstjernen og dernæst ca. 500 m sydøst for Gråsten Slot på en dæmning skære først Kastanieallé, der fører fra slottet til stranden ved Fisknæs, og derefter igennem Østersø. Herefter passeredes den kommunalt ejede Hafenstrasse (nuv. Havnegade), hvorefter kredsbanen mellem Hafenstrasse og Friedrichstrasse atter skulle gennemskære godsdistriktet igennem Stængerodde Skov og gå frem til den planlagte banegård i Gråsten sydvest for Friedrichstrasse. ${ }^{3}$

Selvom der senere foretoges småændringer, må Lenschau altså have været klar over den påtænkte linieføring i hovedtræk allerede den 15. oktober 1896, men han havde altså ingen indvendinger og underskrev protokollen fra forhandlingerne. Den 3. november meddeltes fra Primkenau, at hertugen efter indberetning fra Lenschau var indforstået med de forhandlede betingelser for grundafståelse. Endvidere bad Lenschau den 17. december von Uslar om, at banen igennem 


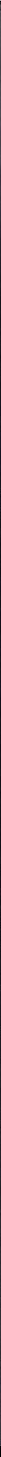

Gråsten med jernbanen indtegnet. Königl. Preuss. Landes-Aufnahme 1877, med ændringer indtil 1910, udgivet 1915. Landsarkivet i Aabenraa.

Stængerodde Skov måtte blive udstukket, så man kunne fjerne de berørte træer inden næste sommer. I sit svar anførte von Uslar, at han nu anså forhandlingerne den 15. oktober for retsbindende. Heller ikke dette protesterede hertugen eller Lenschau imod. Udstikningen måtte dog vente, til kredsjernbanekommissionen havde truffet nærmere beslutning herom. ${ }^{4}$ Umiddelbart tegnede grunderhvervelserne til kredsbanen på Gråsten godsdistrikt sig altså til at forløbe problemfrit. 


\section{Hertugen klager over linieforingen}

Inden anlægsarbejdet kunne påbegyndes, skulle baneplanerne fastlægges og godkendes af regeringspræsidenten for regeringsdistriktet Slesvig-Holsten ved en »landespolizeiliche Prüfung «. Baneplanerne fremlagdes da i foråret og forsommeren 1897 til offentlig indsigt i de berørte kommuner og godsdistrikter. På Gråsten godsdistrikt således hos amtsforstander Lenschau. Eventuelle indsigelser til kredsudvalget kunne ske skriftligt eller mundtligt. I alt indkom tre indsigelser, hvoraf de to vedrørte linieføringen nærmest Gråsten. Den ene kom fra direktør F. M. Bruhn fra »Vereinigte Flensburger, Ekensunder und Sonderburger Dampschiffsfahrtsgesellschaft«, der ejede såvel dampskibsbroen som Kurhuset, som lå øst for den påtænkte bane, samt nogle arealer på og ved den påtænkte banegård. Bruhn fandt, at den planlagte banegård ville skade dampskibsselskabets interesser. Den anden indsigelse kom overraskende fra Lenschau, der meddelte, at hertugen ikke var indforstået med banen igennem Østersø og Stængerodde Skov. Endvidere indgav Lenschau den 1. juli 1897 en klage på vegne af hertugen til den preussiske minister for offentlige arbejder von Thielsen. Dæmningshøjden ville skæmme udsigten fra slottet og gennemskæringen af skoven ville genere ophold her, ligesom der måtte forudses megen trafik ad Hafenstrasse til en evt. kommende havn ved Gråsten. Fra den hertugelige generaldirektions side foresloges det derfor, at banen forlagdes $300 \mathrm{~m}$ mod sydøst udenom Østersø og foran Kurhuset frem til det planlagte banegårdsareal. Fordelen ville være, at der kunne etableres direkte forbindelse mellem banen og dampskibsbroen og en evt. havn. En høj dæmning ville ganske vidst skade Kurhuset, men banelegemet kunne da evt. sænkes. Meromkostningerne ville være begrænset, da kredsbanen kun blev ca. $200 \mathrm{~m}$ længere herved og i øvrigt fandt generaldirektionen, at forslaget også var i Gråsten Landkommunes interesse. ${ }^{5}$

Indsigelsen og klagen vakte selvsagt undren hos landråd von Uslar. Driftsdirektør Kuhrt oplyste dog, at han fra en ikke-navngiven pålidelig kilde havde fået oplyst, at ideen til forlægningen stammede fra dampskibsselskabet, som derved ville styrke sin egen godstrafik, hvilket Kuhrt fandt ville skade både kredsbanen og statsbanen. Landråd von Uslar lod dette gå videre til KED-Altona. Påstanden kan ikke afklares nærmere ud fra det foreliggende kildemateriale. En del af dampskibsselskabets trafik til Gråsten bestod af turister, som ankom 


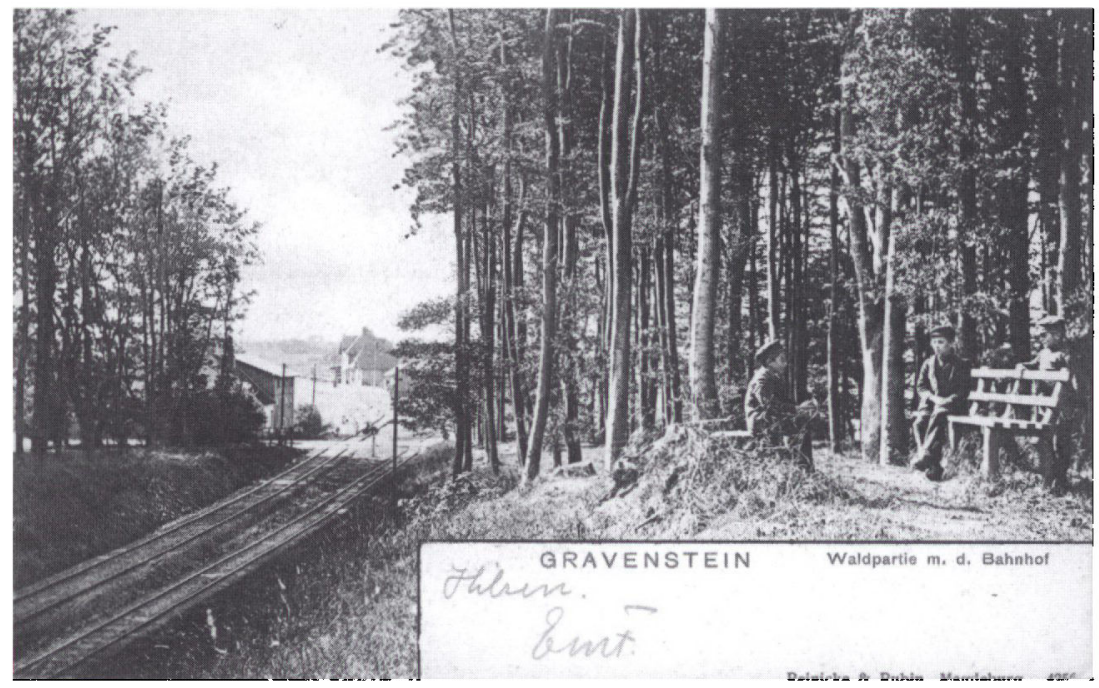

Kredsbanens og statsbanens gennemskæring af Stængerodde Skov, som hertug Ernst Günther $i$ forste omgang accepterede, men som han siden forgæves søgte at forhindre. I baggrunden anes banegårdsarealet $i$ Gråsten. Skoven blev efter den danske stats køb af Gråsten godsdistrikt $i 1921$ videresolgt aret efter til Gråsten kommune, som ryddede skoven med bebyggelse for øje. Foto: Institut for sønderjysk lokalhistorie.

med dampskib fra Flensborg for at besøge slottet og dets omgivelser. Dermed havde dampskibsselskabet ligesom hertugen en interesse $i$ at undgå en forringelse af slottets omgivelser, ligesom man selvsagt har haft interesse i en forøget godstrafik. Grundet dette interessesammenfald kan Kuhrts påstand derfor ikke umiddelbart afvises, selvom selskabet senere afviste den overfor Lenschau. ${ }^{6}$

Da der var giort indsigelser mod baneplanerne, skulle der afholdes planfastsættelsesforhandlinger mellem parterne, hvorefter planerne skulle endeligt fastlægges og godkendes. Selve forhandlingerne foregik den 29. juli i Gråsten, hvor bl.a. repræsentanter fra regeringspræsident Zimmermann og KED-Altona, kredsjernbanekommissionen, kommuneforstander Voigt, Gråsten, samt naturligvis Lenschau og direktør Bruhn var mødt. For strækningen frem til Flensborgchausseen var der ingen indsigelser. Derimod udsattes godkendelsen af den øvrige strækning, indtil ministeren havde besvaret hertugens klage. Minister von Thielsen svarede den 7 . september, at det ikke kunne underkendes, at gennemskæringen ville påvirke Stængerodde Skov, men at der ikke var noget at frygte mht. udsigten fra slottet, da 
dæmningen kun blev $3 \mathrm{~m}$ høj over vandspejlet i søen, ligesom trafik til dampskibsbroen stadig ville være mulig med den planlagte linieføring. Den af hertugen foreslåede forlægning ville derimod afskære Gråsten fra anlæggene foran Kurhuset, hvis der her anlagdes en dæmning, ligesom dette ville betyde en fordyrelse for såvel kredsbanen som statsbanen. ${ }^{7}$ Altså ingen opbakning til hertugen fra ministeren.

Efter ministerens svar afholdtes forhandlinger og politimæssig godkendelse af strækningen fra Flensborgchausseen og frem til Gråsten den 16. oktober 1897. Her aftaltes, at der ved Kastanieallé skulle anlægges en fodgængerovergang i niveau med banen på dæmningen samt anlægges en sti langs med banen på dæmningens østlige side frem til Stængerodde Skov, hvor en gangbro skulle forbinde de overskårne dele af skoven. I selve dæmningen skulle der etableres et gennemløb for vandet $i$ søen. Til regulering af vandstanden skulle gennemløbet forsynes med klapanlæg, der skulle vedligeholdes og betjenes af den hertugelige godsforvaltning. For at mindske de landskabelige skader skulle dæmningen endvidere beplantes. Fra hertugens side betragtede man dog stadig ikke sagen som afsluttet. Da kredsudvalget anmodede hertugen om byggetilladelse for strækningen på godsdistriktet, svaredes fra Primkenau den 17. november, at byggetilladelse kun kunne gives for strækningen frem til Flensborgchausseen. ${ }^{8}$ Sagen om linieføringen var altså endnu ikke afsluttet.

Næste skridt i sagen blev, at minister von Thielsen på baggrund af hertugens andragende anordnede en besigtigelse af forholdene med deltagelse af kommissærer fra ministeriet. Besigtigelsen afholdtes den 2. december 1897 med deltagelse af to ministerialkommissærer samt en kommissær fra overpræsidenten i Slesvig. Herudover deltog repræsentanter fra regeringspræsident Zimmermann, KED-Altona, dampskibsselskabet og en regeringsassessor dr. Ziller fra kredsen, samt kommuneforstander Voigt fra Gråsten. Repræsentanter for hertugen var hofråd Sureu og Lenschau. Fra dampskibsselskabets side kunne man godtage hertugens forslag, såfremt der stadig var uhindret adgang til dampskibsbroen og at dæmningen foran Kurhuset ikke blev højere end $3 \mathrm{~m}$ over havet. KED-Altonas repræsentanter mente derimod, at en sænkning af det planlagte banegårdsareal fra 4,45 m til $3 \mathrm{~m}$ over havet kun yderst vanskeligt lod sig gøre pga. terrænforholdene for statsbanetraceen mod Tørsbøl. Et forslag fra overpræsidentens repræsentant om at forlægge banetraceen mod syd- 


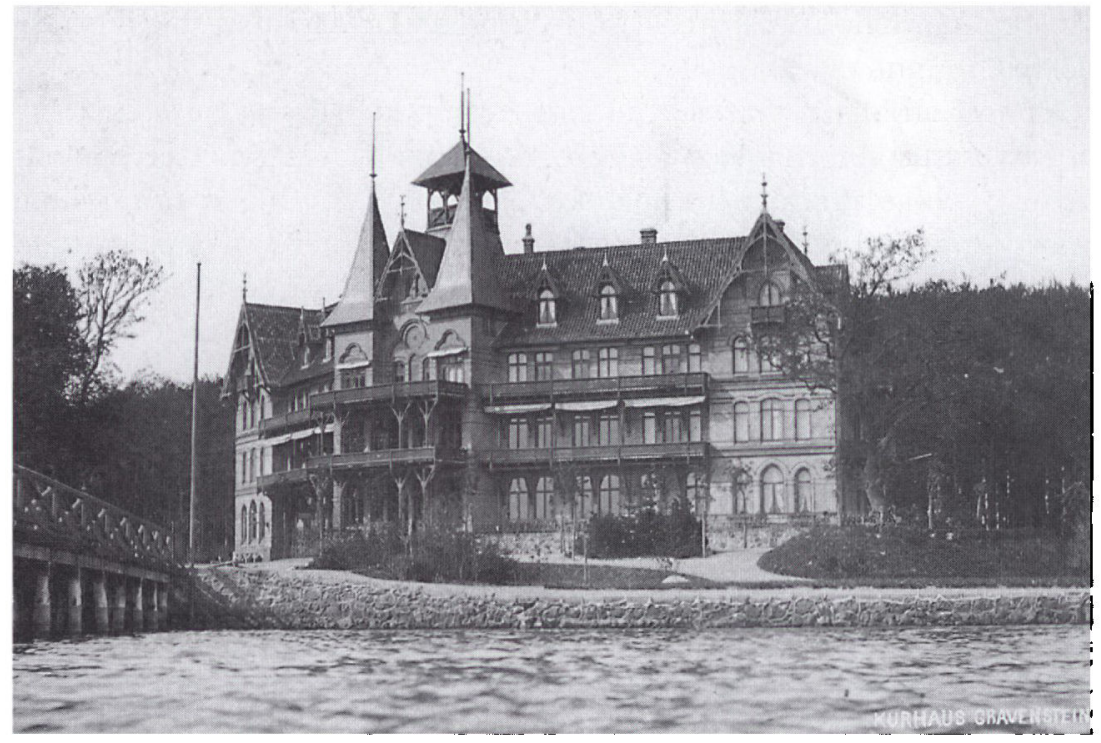

Kurhotellet $i$ Gråsten, foran hvilket hertugen $i 1897$ forgxeves forsogte at fa banelinien forlagt. I baggrunden ses Stængerodde Skov og i forgrunden dampskibsbroen. Hertug Ernst Günther blev i 1906 involveret $i$ planerne om en havn $i$ Gråsten, da han blev formand for en kommission, som arbejdede med dette. Interessen samlede sig især om en havn øst for Kurhotellet. Havnen skulle forbindes med banegdrden, og her var hertugen atter uenig med KED-Altona. KED-Altona ville nemlig forbinde havnen med en smalsporet havnebane i en kurve gennem Stængerodde Skov, mens hertugen for netop at skåne skoven onskede en normalsporet bane langs med statsbanesporet til en vogndrejeskive ved Hafenstrasse og derfra langs med denne til havnen. Parterne nåede ikke til en afklaring for Forste Verdenskrig satte en stopper for alle planer. Da en havn endelig indviedes $i 1923$, blev det med en havnebane foran Kurhotellet, hvor mange af møderne under forhandlingerne om såvel kreds- som statsbanen som havneplanerne $i$ øorigt fandt sted. Foto: Institut for sønderjysk lokalhistorie.

øst bag om Kurhuset afvistes ligeledes fra KED-Altonas side. Kommuneforstander Voigt afviste ligeledes hertugens forslag, da dette ville hindre adgangen til såvel dampskibsbroen som den øst herfor beliggende ladeplads. På Aabenraa kreds' vegne fremførte regeringsassessor Ziller også disse argumenter samt, at når kredsen i sin tid havde accepteret at yde tilskud til statsbanen, var det sket på baggrund af den oprindeligt planlagte linieføring. Den ene af regeringspræsidentens repræsentanter tilsluttede sig dr. Zillers udtalelser og gav udtryk for, at der med forhandlingerne den 15. oktober 1896 forelå en traktat. På baggrund af disse forhandlinger erklærede hof- 
råd Sureu, at han ville anbefale hertugen at trække sit andragende tilbage. 9

Den 16. december afslog minister von Thielsen endegyldigt hertugens andragende om en linieforlægning. Ministeren begrundede dette med de umulige forhold vedrørende dæmningen foran Kurhuset og uhindret adgangsvej til dampskibsbroen samt modstanden fra såvel Gråsten Landkommune som Aabenraa kreds' side. Ulemperne ved den planlagte linieføring kunne dog mindskes ved anlægget af broen i Stængerodde Skov og stien over dæmningen. Ønsker herom kunne fremsættes ved en fornyet politimæssig godkendelse af baneplanerne. En ny planfastsættelsesforhandling og politimæssig godkendelse afholdtes dog først den 3. februar 1898. Af referatet fra mødet fremgår, at hertugen forinden havde fået forelagt tegninger af de allerede aftalte foranstaltninger, og der blev ikke aftalt yderligere foranstaltninger. Direktør Bruhn havde da ikke mere at indvende. Kredsjernbanekommissionens repræsentanter nedlagde påstand om, at der ikke længere forelå indvendinger fra hertugens side mod kredsbanens linieføring. Lenschau synes ikke at have indvendt noget herimod. ${ }^{10}$ Kredsbanens linieføring på Gråsten Godsdistrikt var dermed endeligt fastlagt.

\section{Fortsatte forhandlinger}

Selvom kredsbanens linieføring nu endegyldigt var fastlagt, havde hertugen stadig ikke afgivet nogen byggetilladelse for strækningen fra Flensborgchausseen til Friedrichstrasse. Aabenraa kreds fik da udarbejdet en betænkning om de juridiske forhold hos advokat justitsråd dr. Stemann i Flensborg. Stemann fastslog, at da hertugen oprindeligt havde erklæret sig indforstået med resultatet af Lenschaus forhandlinger den 15 . oktober 1896 og dermed også den planlagte linieføring, kunne Aabenraa kreds kræve erstatning for de tab, som en forsinkelse af anlægsarbejdet pga. den manglende byggetilladelse måtte medføre. På baggrund af betænkningen hævdedes da fra kredsforvaltningens side overfor generaldirektionen i Primkenau, at der forelå en gyldig traktat om grunderhvervelserne, og man anmodede da atter om en byggetilladelse. Endvidere argumenteredes med, at såfremt arbejdet ikke kunne fortsættes, ville kredsen snart være nødsaget til at afskedige arbejdere og returnere et lejet arbejdsspor uden at have gjort brug af dette. Fra hertugelig side krævedes til gengæld 
Indvielsestoget fotograferet ved afgang fra kredsbanegården i Aabenraa 13. februar 1899. Foto: Institut for sonderjysk lokalhistorie.

overfor regeringspræsident Zimmermann, at udtalelsen den 2. december 1897 om at en traktat forelå skulle trækkes tilbage, da Lenschau ikke havde været berettiget til at indgå en traktat og en købssum ikke var aftalt, ligesom man mente, at baneplanerne havde undergået storre ændringer siden forhandlingerne den 15. oktober 1896. I Stængerodde Skov mente hertugen således, at den udstukne gennemskæring var større end oprindeligt aftalt. Hertugen mente da, at spørgsmålet om byggetilladelse nu var op til regeringspræsidentens afgørelse. ${ }^{11}$

Regeringspræsident Zimmermann forespurgte da naturligt nok om sagen hos kredsforvaltningen, som svarede med de samme argumenter som overfor hertugen. Såfremt en byggetilladelse ikke snart opnåedes, anmodede kredsen om, at en ekspropriationsforretning måtte blive igangsat. I sit svar til hertugens privatsekretær den 5. marts gjorde regeringspræsident Zimmermann da også opmærksom på, at kejser Wilhelm II ved en kabinetsordre den 17. januar 1898 havde givet Aabenraa kreds ekspropriationstilladelse til anlægget af kredsbanen. Det havde formentlig sin effekt. I en skrivelse af 9. marts med- 
delte privatsekretæren kredsforvaltningen, at hertugen havde udtalt, at der ikke forelå en traktat, men at han anså Lenschaus forhandlinger, som betegnedes som udkast, for bindende på betingelse af, at regeringspræsidentens repræsentant afgav den onskede erklæring. Kredsudvalget måtte endnu engang anmode om en byggetilladelse. Den kom den 20. marts $1898 \mathrm{i}$ form af et telegram fra hertug Ernst Günther personligt, mens regeringspræsident Zimmermann dagen efter meddelte, at hans repræsentant var villig til at trække sin udtalelse tilbage. ${ }^{12}$

På baggrund af regeringspræsidentens svar bekræftede hertugens privatsekretær overfor kredsudvalget den 6 . april byggetilladelsen og oplyste, at hertugen anerkendte de hidtil førte forhandlinger som basis for en traktat. Endvidere ønskedes forholdene vedr. Stængerodde Skov afklaret ved forhandling med Lenschau. Dette skete den 9. april, hvor Lenschau efter forhandling med von Uslar i Gråsten skrev under på, at gennemskæringen ikke blev bredere men lidt dybere end aftalt, og at træerne på arealet skulle forblive hertugelig ejendom. ${ }^{13}$

Anlægsarbejdet gik nu i gang, og kredsbanen blev indviet under festlige former den 13. februar 1899. Blandt de indbudte var hertug Ernst Günther, som imidlertid måtte melde afbud. Lenschau deltog derimod, men han var vel at mærke indbudt som amtsforstander. ${ }^{14}$

\section{Grunderhvervelserne til statsbanen}

Anlægget af statsbanen fra Sønderborg over Gråsten til Tørsbøl og herfra til henholdsvis Padborg (Flensborg) og Tinglev blev vedtaget af den preussiske Landdag den 29. april 1894. Anlæggelsen skete på betingelse af, at kredsene Aabenraa og Sønderborg bl.a. afgav fri grund til banen. Aabenraa kreds måtte da atter indlede forhandlinger med hertug Ernst Günther. ${ }^{15}$

Et udkast til statsbanens linieføring ved Gråsten forelå allerede i 1895. Det var efter denne plan, at kredsbanens linieføring parallelt med statsbanen projekteredes i 1896. Efter kredsbanens afgrening kort før Flensborgchausseen skulle statsbanen fortsætte i nordøstlig retning og forlade godsdistriktet lidt nordvest for Adsbøl. Detailprojekteringen af statsbanen synes først indledt $i$ begyndelsen af 1898 . Den 14. marts indsendte KED-Altona's »Bauabteilung $2 \ll i$ Gråsten planerne for statsbanen på Gråsten Godsdistrikt. Samtidig anmodedes KED-Altona om at fremskynde den politimæssige godkendelse 
af parallelstrækningen, således at anlægsarbejdet her kunne udføres samtidig med anlægget af kredsbanen. ${ }^{16}$

KED-Altona anmodede da landråd von Uslar om at udvirke en byggetilladelse for statsbanestrækningen hos hertug Ernst Günther. Byggetilladelsen indløb til KED-Altona den 3. april, hvorefter KEDAltona sendte planerne til godkendelse hos regeringspræsident Zimmermann. Denne godkendte planerne den 9. april 1898. Herefter ansøgte KED-Altona minister von Thielsen om tilladelse til, at Aabenraa kreds også kunne udføre anlægsarbejdet for statsbanens vedkommende på den 1,65 km lange parallelstrækning ved Gråsten. Fra Ministeriet for offentlige arbejder afgav man tilladelse hertil den 17. maj $1898 .{ }^{17}$

Som ved kredsbanen skulle den resterende statsbanestrækning gennem Gråsten godsdistrikt også fastsættes og godkendes politimæssigt af regeringspræsidenten. Planerne blev ligeledes først fremlagt til offentlig indsigt hos bl.a. Lenschau i Gråsten i september 1898. Planerne fremsendtes til Lenschau af kredsudvalget i Aabenraa med en bemærkning om, at strækningen parallelt med kredsbanen allerede var blevet politimæssigt godkendt ved godkendelsen af kredsbanen. Det var alene strækningen nordøst for Flensborgchausseen, som nu skulle godkendes. ${ }^{18}$ Med den bemærkning søgte kredsudvalget sandsynligvis at undgå en genoptagelse af balladen om linieføringen gennem Østersø og Stængerodde Skov.

Planfastsættelseforhandlinger mellem parterne afholdtes den 27. september 1898. Efter Lenschaus ønske aftaltes en egentlig bro over Fiskbækken i stedet for det planlagte gennemløb. Broen i Stængerodde Skov fastsloges atter, og efter Gråsten Landkommunes ønske aftaltes endvidere, at Friedrichstrasse skulle sikres med bomme. Ellers var der stort set tilfredshed med de planlagte anlæg.

Tilbage manglede nu blot en traktat om grunderhvervelserne til statsbanen. Den 12. juni 1899 forhandledes i Gråsten mellem von Uslar og to andre medlemmer af kredsjernbanekommissionen og hertug Ernst Günther personligt. Tilsyneladende uden videre problemer afstod hertugen det nødvendige areal. Selve statsbanen blev indviet den 15. juli 1901. Lenschau var atter indbudt, mens hertug Ernst Günther tilsyneladende ikke var indbudt igen. ${ }^{19}$

Forhandlingerne om grunderhvervelserne til statsbanen fik altså et langt glattere forløb end ved forhandlingerne om kredsbanen. Men de store slag om statsbanens linieføring var da også i realiteten ud- 
kæmpet allerede ved fastlæggelsen af kredsbanens linieføring gennem Østersø nær Gråsten Slot, hvor hertug Ernst Günther ikke formåede at rokke meget ved planerne. Tilbage stod derfor blot statsbanens videre forløb mod nordøst gennem marker og eng, der jo lå længere væk fra slottet.

\section{Dæmningen i Østersø}

Selv efter den endelige fastlæggelse af linieføringen gennem Østersø og Stængerodde Skov kom strækningen her til at volde problemer. Dæmningen i Østersø bestod af to parallelle dæmninger af jord, hvor mellemrummet var fyldt op med sand, uden at det underliggende bundslam blev fjernet. Under anlægsarbejdet i 1898 skred dæmningen ud og pressede bundslam op over vandoverfladen på begge sider. Dæmningen kom derved til at optage et større areal af søen end oprindeligt planlagt. På vegne af hertugen forespurgte Lenschau den 11. juni 1899 KED-Altona, om hvorvidt man ville fjerne disse udskridelser. En forpligtelse hertil mente Lenschau allerede var anerkendt. KED-Altona svarede den 25 . juni, at da dæmningen var anlagt af kredsbanen, kunne man ikke forhandle herom, ligesom man ikke kunne anerkende nogen forpligtelse til at fjerne udskridelserne. Endvidere ville en fjernelse underminere dæmningen og dermed være til fare for sikkerheden. Lenschau synes ikke at have svaret herpå i første omgang, men ifølge et udateret og tilsyneladende aldrig underskrevet traktatudkast om grunderhvervelserne til kredsbanen omtales dog, at udskridelserne ikke må fjernes men skal planeres og beplantes. ${ }^{20}$

Ved forhandlingerne den 12. juni 1899 krævede hertug Ernst Günther, at udskridelserne enten skulle fjernes, eller at der skulle ydes erstatning herfor. Endvidere hævdede hertugen, at Fiskbæk gods havde ret til at stemme vandet fra Fiskbækken op i Fiskbæk Gruppe, som statsbanen passerede henover nordøst for Adsbøl-Fiskbæk vejen. Dette skulle KED-Altona tage hensyn til ved anlægget af statsbanen. Såfremt KED-Altona ville efterkomme disse onsker, var hertugen villig til at give afkald på anlægget af broen i Stængerodde Skov. Den 15. august forespurgtes fra Primkenau, om Aabenraa kreds ville yde erstatning, såfremt hertugen gav afkald på en bro i Stængerodde Skov. Landråd von Uslar orienterede KED-Altona om skrivelsen og mente, at hertugen ved at løse denne sag særskilt ville sikre sig mulighed for fortsat at kunne fremsætte andre krav mod kredsen og 


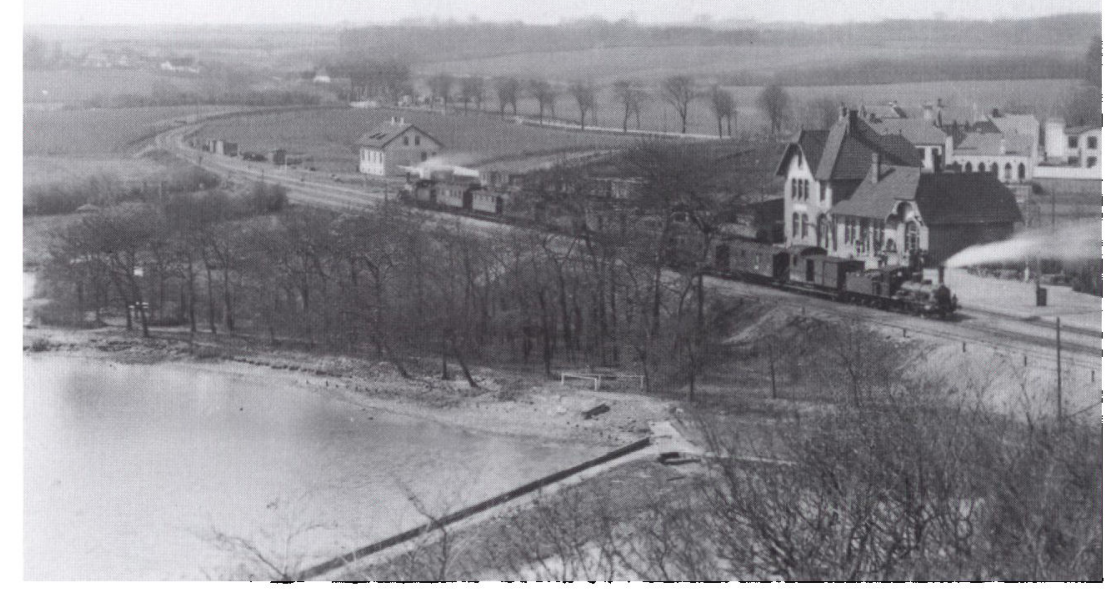

Statsbanegården $i$ Gråsten set mod sydvest. I baggrunden ses Flensborgchausseens skæring med statsbanen vest for byen, hvor der efter hertugens henvendelse anlagdes et ledvogterhus og bomanlæg $i$ 1912. Foto: Gråsten kommunes lokalhistoriske arkiv.

KED-Altona. Retten til at stemme vandet op kunne von Uslar ikke anerkende og foreslog KED-Altona, at man afgav et fælles svar til hertugen. Det accepterede KED-Altona. I svaret den 8. september til hertugen afvistes, at jernbaneanlæggene skulle have nogen indvirkning på evt. fiskeopdræt i Fiskbæk Gruppe. Broen i Stængerodde Skov kunne undlades, hvis hertugen var indforstået hermed, men hertugen havde dog ikke ret til erstatning, hvis broen ikke tjente til at afbøde ulemper for godsdistriktet opstået ved baneanlæggene. Dog var man villig til at yde erstatning for broen, hvis hertugen ville give afkald på alle andre fastsatte anlæg vedr. fiskedamme. Udskridelserne i Østersø ville man fortsat ikke fjerne. Hvis hertugen ikke ville acceptere en planering og beplantning, anmodedes han om at afstå arealerne til kredsen. Forpligtelsen til at anlægge et sidespor ved Overstjernen anerkendtes fortsat. ${ }^{21}$

Fra Primkenau svaredes KED-Altona den 14. september, at hertugen ville acceptere en erstatning på $2.500 \mathrm{M}$, som udgjorde KED-Altonas andel af udgifterne til broen i Stængerodde Skov, som hertugen 
så gav afkald på, ligesom hertugen ville give afkald på erstatningskrav vedr. anlæg i forbindelse med fiskeopdræt. Stemmeværk mv. skulle da anlægges på hertugens regning. Man kunne derimod ikke pt. oplyse, om sidesporet ved Overstjernen stadig ønskedes anlagt. Kunne KED-Altona ikke godtage dette, forbeholdt hertugen sig sin stilling mht. anlæg af stemmeværk og fjernelse af udskridelserne i Østersø. ${ }^{22}$

KED-Altona og kredsjernbanekommissionen afgav igen et fælles svar til generaldirektionen i Primkenau. Man ville ikke anerkende nogen forpligtelse til anlæg af et stemmeværk af nogen art, ligesom man ikke kunne acceptere en fjernelse af udskridelserne i Østersø. Herefter synes der at være blevet stille $i$ sagen. Først den 10. april 1900 skrev Lenschau til von Uslar og androg på vegne af hertugen om, at udskridelserne i Østersø blev opmålt. Lenschau mente selv, at formålet var at få udarbejdet en betænkning, som fastslog at udskridelserne kunne fjernes uden fare. Umiddelbart findes der ikke videre om dette i sagsakterne. I september bad ministeren for offentlige arbejder om at få forelagt traktaterne/aftalerne om grunderhvervelserne, men heller ikke om dette foreligger der yderligere i sagsakterne. ${ }^{23}$

\section{Hertugen klager til distriktsudvalget}

Uanset hvor meget der evt. blev forhandlet i løbet af 1900, må hertugen på et tidspunkt have ment, at han ikke kom længere ved forhandling med KED-Altona og Aabenraa kreds. Den 19. marts 1901 lod hertug Ernst Günther nemlig indgive en klage til distriktsudvalget i Slesvig. Udskridelserne i Østersø havde skadet den hertugelige fiskefangst i søen og forårsaget en værdiforringelse af Gråsten Slot pga. den ødelagte udsigt mod sydøst. Det påstodes nu på baggrund af undersøgelser foretaget af professor Müller, Braunschweig, at dæmningen var så dårligt udført, at der var fare for, at den skulle skride yderligere ud. Ved Kastanieallé var trappeanlægget ikke i ordentlig stand og en parallelsti ikke anlagt. Endelig var anbringelse af bomme ved Friedrichstrasse nødvendig. Med baggrund i ekspropriationsloven af 1874 mente hertugen, at der var indledt en ekspropriationssag i 1896, og at denne endnu ikke var afsluttet. Da såvel hertugelige som offentlige interesser, bl.a. ved Kastanieallé, var truet, anmodede hertugen distriktsudvalget om at fastsætte, hvilke foranstaltninger der burde foretages til sikring af Østersø mod de af 


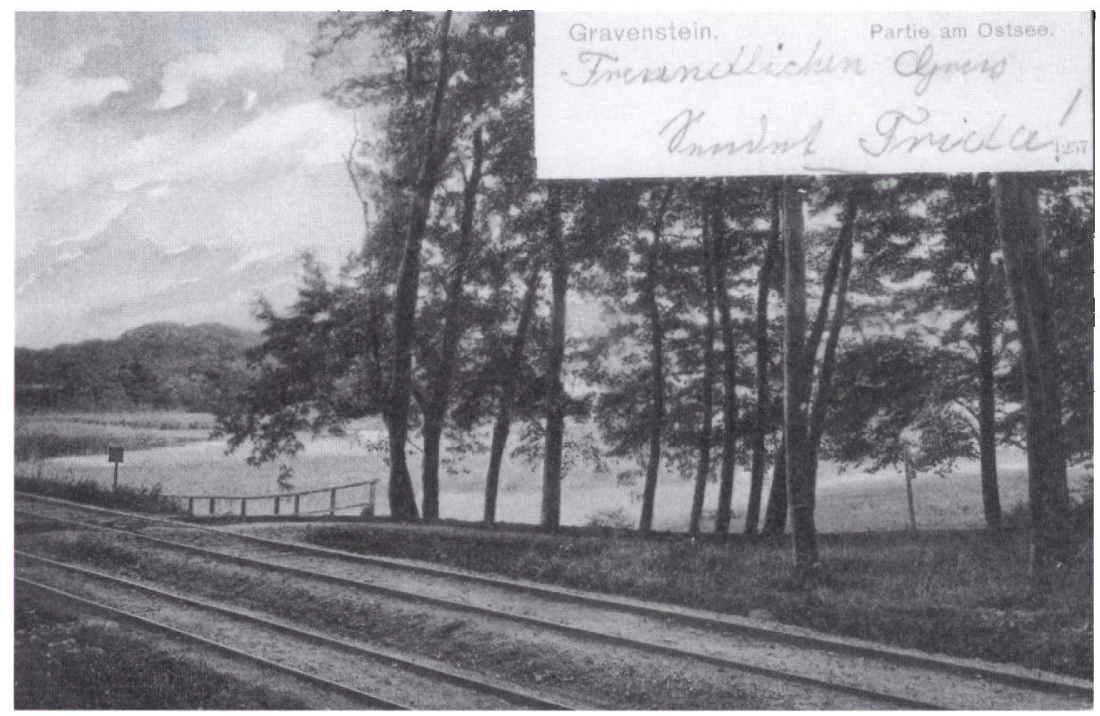

Kastanieallés skæring med kreds- og statsbanerne for anlægget af viadukten. I baggrunden ses Østersø med de opsvulmede arealer. Sporet $i$ forgrunden er statsbanens. Bemærk skiltet lidt nede af Kastanieallé mod slottet. Det har sikkert adviseret de gående om den tværgående jernbanetrafik. Foto: Institut for sonderjysk lokalhistorie.

dæmningen forårsagede skader og til sikring af offentlige interesser. Foranstaltninger som hertugen mente, at det jf. ekspropriationsloven påhvilede såvel kredsbanen som statsbanen at tilvejebringe. ${ }^{24}$

KED-Altona og Aabenraa kreds afgav da en fælles moderklæring til distriktsudvalget med anmodning om, at distriktsudvalget afviste hertugens klage. Arealerne i Østersø var erhvervet ved en traktat mellem hertugen og Aabenraa kreds og dermed i fri handel og ikke ved ekspropriation. At dæmningen ikke var anlagt på forsvarlig vis afvistes ligeledes. Tværtimod ville det være farligt at fjerne udskridelserne, og en politimæssig forordning med forbud herimod burde udstedes, hvilket man ville anmode om ved den politimæssige godkendelse af den snart færdigt anlagte statsbane. Dæmningen lå i øvrigt ca. $500 \mathrm{~m}$ fra slottet, så en værdiforringelse afvistes også. Mht. Kastanieallé var trappeanlægget ikke færdiganlagt endnu og ved Friedrichstrasse ville kun statsbanen blive sikret med bomme. Inden distriktsudvalget afgav svar foretoges endvidere en besigtigelse af området af driftsdirektør Kuhrt og direktør Brauer fra distriktsudvalget. Distriktsudvalget afgav svar den 8 . juli 1901. Distriktsudvalget mente 
ligesom KED-Altona og Aabenraa kreds, at der ikke havde været tale om ekspropriation. Dermed var det ikke ekspropriationsloven af 1874 , men derimod jernbaneloven af 3 . november 1838 der gjaldt. Og dermed var distriktsudvalget ikke beslutningskompetent. Det var derimod vedkommende politimyndighed, der kunne anordne foranstaltninger til sikring af nabogrunde og offentlige interesser. Hertugens andragende blev derfor afvist. ${ }^{25}$

Hertugen accepterede imidlertid ikke distriktsudvalgets afgørelse og ankede derfor denne til distriktsudvalget igen, der tilsyneladende videresendte anken til ministeren for offentlige arbejder. Endnu engang hævdedes fra hertugelig side, at der var tale om en uafsluttet ekspropriationsforretning. KED-Altona og kredsudvalget afgav atter en fælles moderklæring og afviste igen, at der var tale om ekspropriation. Ministeren afgav svar den 21. november 1901. Ministeren nåede efter en nøje gennemgang af de juridiske forhold frem til, at der overhovedet ikke havde fundet en egentlig fastsættelse af diverse sikringsanlæg sted. Derfor var den ønskede fastsættelse af foranstaltninger gennem distriktsudvalget jf. ekspropriationsloven ikke tilladelig. Hertugens klage blev altså også afvist af ministeren, uden at dette dog gav en nærmere afklaring af situationen. ${ }^{26}$

I mellemtiden havde hertug Ernst Günther haft en sideløbende kontrovers med landråd von Uslar. Ved den politimæssige godkendelse af den færdige statsbane den 14. juni anmodede KED-Altonas repræsentanter om, at der udstedtes et forbud imod fjernelse af udskridelserne. Idet von Uslar fandt, at Lenschau var inhabil, lod han da amtsforstander Bruhn, Skovbølgård, udstede et sådant forbud med trussel om bøde på $60 \mathrm{M}$ eller en uges fængsel. Hertugen lod indgive en klage over forbudet, men von Uslar gik kun med til at fjerne straftruslen. Hertugen indgav da klage herover til regeringspræsidenten, uden at der dog skete videre i første omgang. ${ }^{27}$

\section{Forhandlingerne den 25. januar 1902}

Ministeren pålagde efter sit afslag KED-Altona at træde i forhandling med hertug Ernst Günther. Parterne mødtes da til forhandling i Gråsten for at bilægge stridighederne den 25. januar 1902. For KED-Altona mødte tre repræsentanter, Aabenraa kreds blev repræsenteret af landråd von Uslar og driftsdirektør Kuhrt, mens hertug Ernst Günther blev repræsenteret af hertugelig bygmester Sindermann og 
Lenschau, der ved forhandlingen kunne fremvise en fuldmagt fra hertugen.

Ved forhandlingen enedes parterne om, at de oprindeligt planlagte arealer i Østersø til kredsbanen og statsbanen var retmæssigt erhvervet, men at salgstraktaten, dvs. forhandlingerne den 15. oktober 1896 og traktaten af 12. juni 1899, ikke omfattede de arealer, som udskridelserne optog, og som derfor måtte erhverves og overgå til statsbanerne. Hertugen bevarede ret til fiskeri i Østersø. Fra hertugelig side krævedes da for arealerne i Østersø $24 \mathrm{M} /$ ar og $30.000 \mathrm{M}$ for de opståede ulemper. Dette afviste von Uslar imidlertid. Hertugens repræsentanter tilbød da, at hertugen gav afkald på erstatning, hvis der for arealerne i Østers $\varnothing$ betaltes $24 \mathrm{M} / \mathrm{ar}, \mathrm{og}$ at de samlede omkostninger på $5.000 \mathrm{M}$ ved anlæg af en bro i Stængerodde Skov udbetaltes. Udover den i traktaterne aftalte erstatning skulle yderligere $1.600 \mathrm{M}+$ rente fra den 1 . oktober 1899 at regne udbetales i mererstatning. Hertugen ville endvidere give afkald på de opstillede bomme ved Friedrichstrasse. Hvis hertugen endvidere gav afkald på et sidespor ved Overstjernen, skulle yderligere $1.000 \mathrm{M}$ udbetales. Landråd von Uslar antog dette tilbud, men han ville dog til slut ikke anerkende nogen forpligtelse til at udbetale mererstatningen. KED-Altona accepterede at udbetale sin andel af omkostningerne til broen i Stængerodde Skov. Hertugens repræsentanter ophævede endvidere klagepunkterne i klagen af 19. marts 1901 til distriktsudvalget. Fra hertugelig side erklæredes endvidere, at hertugen kunne rejse erstatningskrav vedr. uforstyrret færdsel ved Friedrichstrasse og Kastanieallé, samt senere gøre krav på anlæg af et stemmeværk ved Sønderkoppel ved Fiskbækken. Landråd von Uslar erklærede dog, at hertugen ved de indgåede traktater allerede havde affundet sig vedr. disse krav. Hertugens repræsentanter synes ikke at have indvendt yderligere herimod. ${ }^{28}$

Fra generaldirektionen i Primkenau meddeltes den 30 . januar, at hertug Ernst Günther ville godtage forliget mod en erstatning på $10.000 \mathrm{M}+$ renter for de for Gråsten Godsdistrikt ved baneanlæggene opståede ulemper og da give afkald på sidesporet ved Overstjernen. Dog skulle statsbanerne tillade et af den hertugelige forvaltning planlagt sidespor på fri strækning såvel som overføring af sidesporet fra kredsbanen gennem statsbanesporet ved Overstjernen, hvor hertugen påtænkte at anlægge et teglværk og en cementfabrik. Dette havde KED-Altona dog allerede accepteret ved forhandlingerne den 25 . januar. Den 14. februar gav hertugen personligt udtrykkeligt afkald på 


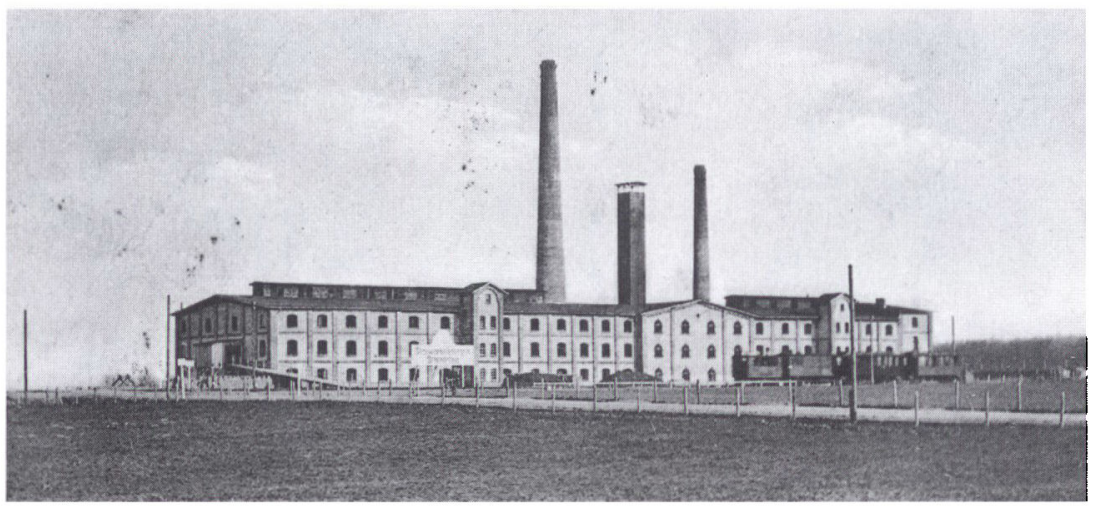

Gråsten Teglværk, som hertug Ernst Günther lod opfore 1903-04. Den påtænkte cementfabrik blev derimod ikke til noget. Da hertugen $i 1902$ havde givet afkald på anlæg af sidespor her ved kredsbanen som erstatning for de opståede gener, måtte amtsforstander Lenschau på vegne af teglværket forhandle særskilt om dette $i$ 1902, hvilket dog skete uden nogen komplikationer. Også ved statsbanen anlagdes et sidespor. Da teglværket måtte standse driften $i$ 1916, fjernedes sidesporet ved kredsbanen, men det genanlagdes dog $i$ 1923, da varket under en ny dansk ejer genoptog driften. Bemærk kredsbanetoget t.h., der er på vej mod Aabenraa. Foto: Institut for sønderjysk lokalhistorie.

broen i Stængerodde Skov og bommene ved Friedrichstrasse, samt ophævede alle videre krav mod KED-Altona og Aabenraa kreds. KED-Altona accepterede dette og anså da forhandlingerne den 25. januar 1902 for juridisk bindende. Aabenraa kreds ved landråd von Uslar synes da også at have accepteret dette uden yderligere kommentarer. ${ }^{29}$

Tilbage stod nu blot at forhandle betalingen for selve de afståede arealer. Forhandlingerne herom trak tilsyneladende ud. Først i juni 1903 nåede Aabenraa kreds og hertugen til enighed om en samlet pris på 32.953,90 M for et areal inkl. udskridelserne i Østersø på 3,8346 ha. ${ }^{30}$

\section{Viadukten ved Kastanieallé}

På trods af forhandlingerne i 1902 skulle forholdene ved Kastanieallé, der var åbnet for offentligheden af hertugen, senere få et efterspil. Som nævnt blev Kastanieallé lige nordøst for Østersø ved baneanlæggene afbrudt af en dæmning, der var 2,5 m høj, og der etableredes en fodgængerovergang via trætrappetrin. Da banerne umiddelbart efter 
Kastanieallé beskrev en kurve yderligere mod nordøst, er det let at forestille sig de ringe oversigtsforhold for fodgængerne. Dog opstilledes formentlig allerede ved anlæggelsen et såkaldt drejekors på statsbanesiden, således at fodgængere her ikke kunne gå over sporene uden at måtte standse op. Ved anlægget ville man ikke etablere ramper for kørende trafik, da man derved skulle fjerne for mange af træerne langs Kastanieallé. En viadukt synes ikke at have været overvejet. $^{31}$

Kastanieallé dukkede op igen i august 1906, da Lenschau i sin egenskab af amtsforstander skrev til den konstituerede landråd Dryander og påpegede de dårlige forhold. Trafikken var steget, og der var lokalt frygt for, at hertug Ernst Günther ville lukke vejen igen for offentligheden. Det ville ødelægge Gråstens fortsatte beståen som bade- og turiststed. En form for bomme måtte da opstilles eller en viadukt anlægges. Lenschau bad Dryander foranledige en forhandling om forholdene med regeringspræsidenten. Dryander videresendte da Lenschaus skrivelse til regeringspræsidenten og tilsluttede sig Lenschaus synspunkter. Selvom hertugens advokat i en klage til regeringspræsident Ukert i 1913 hævdede, at der fandt overvejelser sted i 1906/7, kan der ikke findes yderligere sagsakter herom. Nogen videre resultater synes Lenschaus skrivelse i 1906 altså ikke at have afstedkommet. $^{32}$

Med hensyn til trafikken bør nævnes, at der endnu i 1906 som ved åbningen i 1901 kørte 8 daglige persontogpar på statsbanen mellem Sønderborg og Gråsten. Antallet steg dog successivt $i$ årene herefter til 10 persontogpar i 1911. På kredsbanen kørte der 1906 som ved åbningen i 18995 togpar. I 1908 øgedes antallet til 6 for igen at blive reduceret til 5 i 1913. Om antallet af fodgængere på Kastanieallé var øget lader sig ikke afgøre her, men hverken kreds- eller statsbanen havde altså forøget faren ved passage af Kastanieallé endnu i 1906. ${ }^{33}$

\section{Hertugen klager til ministeren}

Forholdene ved Kastanieallé dukkede atter op i 1911, da hertug Ernst Günther den 28. juli personligt fra Gråsten i skrivelse beklagede sig til daværende minister for offentlige arbejder von Breitenbach. Hertugen påpegede, at han oprindeligt havde taget afstand fra afbrydelsen af Kastanieallé, men at jorden til statsbanen var afstået efter forhandlingerne den 12. juni 1899, og at endnu uklare punkter var afklaret ved 
forhandlingerne den 25. januar 1902. Dog havde hertugens repræsentanter erklæret, at der senere kunne kræves erstatning for hindring af færdslen ved Kastanieallé. En lige lovlig rosenrød fremstilling af trakasserierne må man sige.

Hertugen androg nu minister von Breitenbach om, at der enten anlagdes en viadukt under eller en bro over banen tæt derved. Viadukten skulle være farbar for vogntrafik. Endvidere påpegede hertug Ernst Günther, at sikkerheden ved såvel Friedrichstrasse som ved skæringen med Flensborgchausséen vest for Gråsten var meget dårlig pga. oversigtsforholdene og manglende bomme. Hertugen bad da om, at ministeren sendte en specialkommissær til Gråsten for at besigtige forholdene og tilføjede, at denne situation ikke ville være opstået, hvis man, som hertugen havde foreslået, havde forlagt banen syd om Kurhuset. Endvidere hævdede hertugen, at statsbanen til Sønderborg var en af de mest rentable strækninger i modsætning til kredsbanen. Vel sagtens en slet skjult undskyldning for ikke at henvende sig til kredsen. ${ }^{34}$

Minister von Breitenbach sendte da specialkommissær Blum til Gråsten, hvor denne den 4. august fik forevist lokaliteterne af hertugen selv. Hertugen erklærede her, at en viadukt ved Kastanieallé med en gennemkørselshøjde på $3 \mathrm{~m}$ var tilstrækkelig, hvilket Blum mente godt kunne lade sig gøre. En bro mod nordøst ville derimod være for dyr. Forholdene ved Kastanieallé fandt Blum var farlige pga. af oversigtsforholdene og et mangelfuldt trappeanlæg især på kredsbanens side. Ved Friedrichstrasse fandt Blum også, at oversigtsforholdene var dårlige og anbefalede her, at de i 1902 fjernede bomanlæg blev geninstalleret. Derimod fandt Blum forholdene ved Flensborgchausseen vest for Gråsten i orden. Dog kunne oversigtsforholdene forbedres ved at udfladige vejens stigninger op til overskæringen. Endelig fik Blum også forevist en vej længere mod vest, der også var blevet afbrudt af statsbanen. Her mente Blum, at en vej evt. kunne føres langs banetraceens nordlige side hen til Flensborgchausseen. ${ }^{35}$

Sagen blev nu overdraget til KED-Altona. Den 29. august 1911 foretog præsidenten for KED-Altona således personligt en besigtigelse af forholdene sammen med repræsentanter for kredsjernbanekommissionen. I løbet af september udarbejdedes hos KED-Altona tegninger og beregninger af omkostningerne ved mulige løsninger de pågældende steder i Gråsten. På baggrund heraf skrev minister von Breitenbach til hertugen og erklærede sig indforstået med anlæg af en vi- 
adukt ved Kastanieallé. Halvdelen af omkostningerne på $12.000 \mathrm{M}$ tilfaldt egentlig kredsbanen, men grundet disses dårlige økonomi, som hertugen jo selv havde påpeget, kunne viadukten kun anlægges, hvis hertugen selv betalte de $6.000 \mathrm{M}$. Friedrichstrasse skulle sikres ved geninstallering af bomanlæg, og ved Flensborgchausseen skulle der ligeledes installeres bomme og et ledvogterhus opføres. Derimod ville ministeren ikke anlægge sidevej fra vejen længere mod vest, da jernbanen ingen interesse havde heri. ${ }^{36}$

Det behagede ikke umiddelbart hertug Ernst Günther, at ministeren ville have hertugen selv til at betale $6.000 \mathrm{M}$ til viadukten. Hertugen påstod således, at man havde beregnet et tab på $13.870 \mathrm{M}$ for Gråsten Godsdistrikt pga. baneanlæggene. I januar 1912 accepterede hertugen dog at betale til viadukten, mod at kredsbanen forpligtedes til at yde erstatning. Hertugen anmodede KED-Altona om, at man sendte et traktatudkast herom. Det måtte her udtrykkelig udtales, at hertugen kun betalte under forbehold af at kunne gøre kredsbanen erstatningspligtig. KED-Altona sendte det ønskede traktatudkast til hertugen i januar 1912, men formentlig pga. de nedenfor nævnte trakasserier med Aabenraa kreds underskrev generaldirektionen traktatudkastet den 19. maj 1913 og indbetalte de $6.000 \mathrm{M}$ i juni. Den 7. oktober 1913 meddeltes, at anlægsarbejdet med viadukten var iværksat. Anlæggene ved Friedrichstrasse og Flensborgchausseen var da allerede bevilliget og anlagt $\mathrm{i}$ henholdsvis 1911 og 1912. ${ }^{37}$

\section{Hertugens andragende til Aabenraa kreds}

$\mathrm{Da}$ det af minister von Breitenbach og KED-Altona blev overladt til hertug Ernst Günther selv at få Aabenraa kreds til at betale til viadukten, lod hertugen den 19. februar 1912 indgive andragende om betaling af de $6.000 \mathrm{M}$.

Kredsjernbanekommissionen behandlede hertugens andragende på et møde den 6. marts, hvor der ikke deltog en repræsentant fra regeringspræsidenten, hvilket ellers ofte skete. Så vigtigt var hertugens andragende altså ikke. Regeringsassessor dr. Eichorn redegjorde for de juridiske forhold. Dr. Eichorn mente ikke, at der efter fastsættelsen af anlægget i 1898 forud for kredsbanens anlæg kunne gøres yderligere krav gældende fra nabogrundejere jf. småbaneloven af 1892, mens kredsbanens driftsdirektør Paap mente, at forholdene ved Kastanieallé var i orden, som de var, ligesom kredsbanens økonomi ikke tillod 


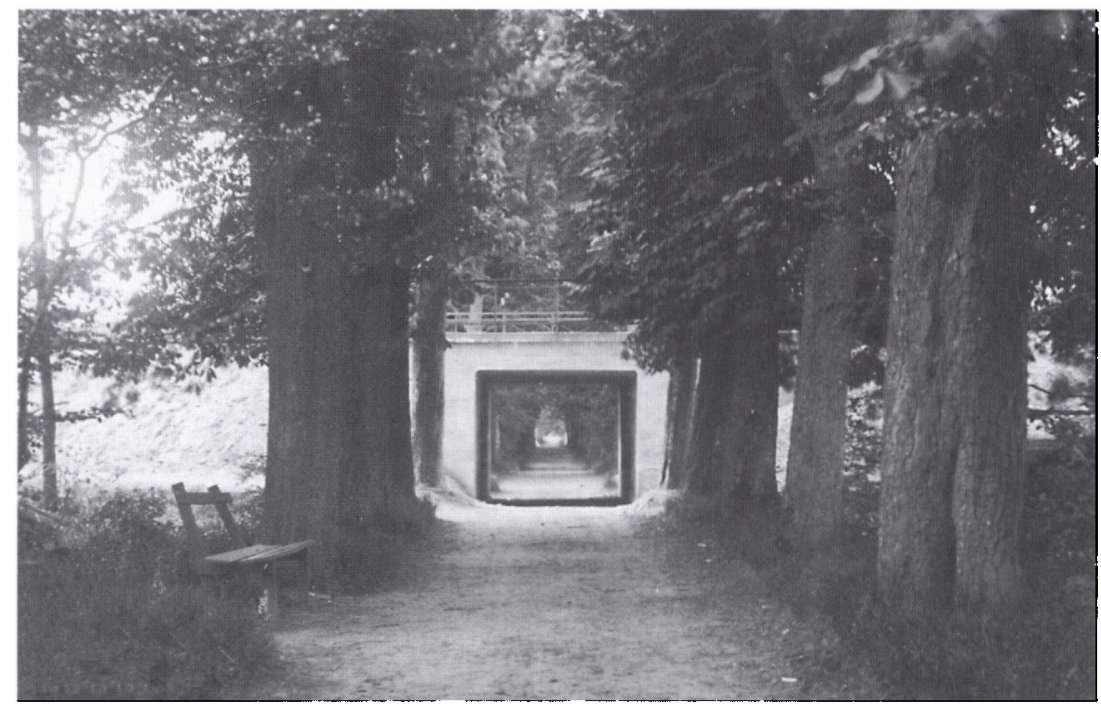

Den $i 1913$ opforte viadukt under kredsbanen og statsbanen ved Kastanieallé set $i$ retning mod slottet. Viadukten er senere blevet erstattet af en noget lavere tunnel for cyklister og gående. Foto: Institut for sønderjysk lokalhistorie.

en udgift af den nævnte størrelse. Kredsjernbanekommissionen vedtog da at indstille til kredsdagen at afvise hertugens andragende, men dog tilbyde at overtage vedligeholdelsesudgifterne. På kommissionens møde udtrykte borgmester Rickmers, Aabenraa, betænkelighed ved at lade sagen behandle på et åbent kredsdagsmøde, hvor pressen ville få nys om sagen med hertug Ernst Günther, der jo var kejser Wilhelm II's svoger. Det blev accepteret og kredsdagen behandlede hertugens andragende den 26. marts 1912, hvor det enstemmigt vedtoges, at afvise hertugens andragende. ${ }^{38}$

Regeringspræsident Ukert forsøgte den 31. juli at formidle et kompromis, hvorefter Aabenraa kreds skulle betale hertug Ernst Günther $2.500 \mathrm{M}$. Om dette skete på initiativ af hertugen er ikke klart, da akterne herom er næsten ulæselige, men i hvert fald afvistes dette af kredsen.

Regeringspræsident Ukert blev atter bragt på banen i august 1913, da hertug Ernst Günther via sin advokat justitsråd dr. Löhmann, Flensborg, forsøgte at overbevise ham om, at regeringspræsidenten som politimyndighed overfor kredsbanen var såvel beføjet som forpligtiget til at pålægge kredsbanen at medvirke til viadukten, da den- 
ne var $\mathrm{i}$ både offentlighedens som godsdistriktets interesse. Regeringspræsident Ukert afviste imidlertid, at forholdene var af en sådan karakter, at de kunne begrunde politimæssig indgriben eller tilsynsforanstaltninger over for Aabenraa kreds. Dermed var der heller ingen begrundelse for, at Aabenraa kreds skulle betale til viadukten. Regeringspræsident Ukert ville altså nok formidle et kompromis, men tvinge Aabenraa kreds til at betale til hertugen ville han ikke. ${ }^{39}$

\section{Hertugen sagsøger Aabenraa kreds}

Næste skridt i viaduktsagen blev, at hertug Ernst Günther i oktober 1913 sagsøgte Aabenraa kreds ved Landsretten i Flensborg for at få refunderet de $6.000 \mathrm{M}$, som han havde betalt, samt renter og sagsomkostninger. Hertugens advokater, dr. Löhmann og dr. Trenckner, argumenterede for, at forholdene ved Kastanieallé havde været til ulempe for såvel hertugen som offentligheden. Ved at anlægge viadukten havde KED-Altona og ministeren da også anerkendt dette. Kredsen var lige så forpligtet til at medvirke til at afbøde faren for offentligheden som staten jf. jernbaneloven af 1838 og småbaneloven af 1892. Denne forpligtelse gjaldt også efter den endelige fastsættelse af baneanlægget, da kredsbanen selv havde forårsaget de opståede ulemper og farer. Om der forelå et politimæssigt pålæg var betydningsløst, da det var nødvendigheden af indgreb, der var det afgørende. ${ }^{40}$

Aabenraa kreds' advokater, dr. Christians og dr. Leonhardi, Flensborg, hævdede derimod, at det ved den politimæssige godkendelse af anlægget var blevet fastlagt, hvilke foranstaltninger der skulle træffes, for at afbøde ulemper for nabogrundejerne opstået ved baneanlægget. Her havde hertugen ikke krævet nogen viadukt, hvorfor hertugens krav burde afvises. Det hidtidige trappeanlæg havde opfyldt alle krav. Hidtil var der jo ikke sket uheld på stedet. I øvrigt var driftsforholdene for kredsbanen forskellige fra statsbanens, hvor sikkerhedskravene var strengere. At KED-Altona havde anerkendt nødvendigheden af en viadukt for statsbanernes vedkommende, medførte derfor ikke nødvendigvis, at kredsbanen så også var forpligtiget til at medvirke til viadukten. Da vejen var hertugens private vej, kunne han i øvrigt bare lukke den igen, hvis forholdene blev for farlige. ${ }^{41}$

De to parters advokater nåede hver især at afgive to skriftlige indlæg til Landsretten, ligesom der var forhandling mellem advokaterne ved retten en enkelt gang den 26. november 1913. Imidlertid fandt 


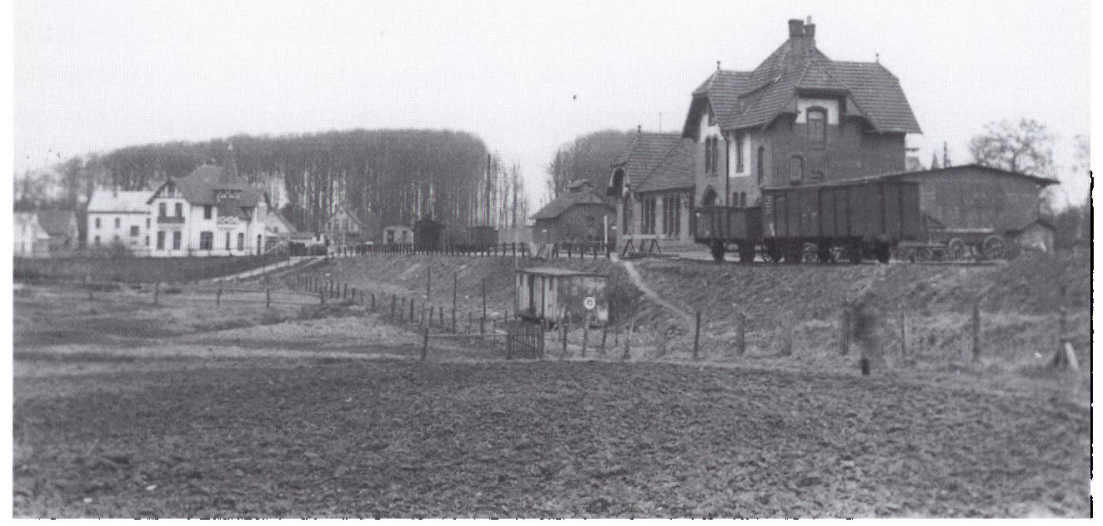

Banegårdsarealet $i$ Gråsten o. 1910. Til højre statsbanegdirden, hvor der fra 1901 var fællesekspedition for stats- og kredsbanen, indtil kredsbanen opforte sin egen stationsbygning $i$ 1907. Den ses til venstre $i$ billedet. I baggrunden den nu forsvundne Stængerodde skov, hvor banernes af hertugen omstridte gennemskæring tydeligt ses mellem de to stationsbygninger. Det fremgår, hvorledes banerne er anlagt på en dæmning henover et lavtliggende areal. Også udsigten fra Gråsten by, som ligger t.v. udenfor billedet, blev påvirket af jernbanernes komme. Foto: Gråsten kommunes lokalhistoriske arkiv.

sagen ikke sin løsning ved retten. Den 26. november erklærede kredsudvalget sig enstemmigt rede til at slutte forlig med hertugen og betale $3.000 \mathrm{M}$ under forbehold af kredsdagens tilslutning. Samtidig udtrykte kredsudvalget, at det var vigtigt hurtigst muligt at skabe et godt forhold til hertugen. Hvem der tog initiativ hertil, fremgår ikke af sagsakterne. Men det er nærliggende at antage, at Aabenraa kreds' nye landråd Siemon var initiativtageren. Som ny landråd kunne han have motiv til vise initiativ og handlekraft. Via regeringspræsident Ukert formidledes kredsudvalgets beslutning til hertugen. Fra generaldirektionen i Primkenau meddeltes tilbage den 14 . december, at hertugen var rede til at antage forliget, og at det også for hertugen var vigtigt at skabe det bedst mulige forhold til Aabenraa kreds. Dog ville han videreføre retssagen, hvis kredsdagen ikke godtog forliget. ${ }^{42}$ 
Den 7. februar 1914 vedtog kredsjernbanekommissionen enstemmigt forligsforslaget. De $3.000 \mathrm{M}$ skulle tages af kredsbanens driftsoverskud for regnskabsåret 1913. Forligsforslaget kom til behandling i kredsdagen den 26. februar. Landråd Siemon begrundede her forslaget med, at trods tvivl om berettigelsen af hertugens krav måtte man også regne med muligheden for en domstolsafgørelse i kredsens disfavør, ligesom en langvarig retssag heller ikke var i kredsens interesse. Med Aabenraa kreds' svage økonomi in mente virker landråd Siemons begrundelse troværdig. Amtsforstander Zittelmann, Gråsten, udtrykte på mødet bekymring for, at hertugen senere ville lukke vejen igen, men dette afviste landråd Siemon. Kredsdagen endte da med enstemmigt at vedtage forligsforslaget. ${ }^{43}$

Kredsdagens beslutning sendtes atter via regeringspræsident Ukert til hertug Ernst Günther, som den 7. marts 1914 personligt takkede for beslutningen og forsikrede, at han ikke ville lukke Kastanieallé for offentligheden. Aabenraa kreds' betaling af selve de $3.000 \mathrm{M}$ lod dog vente på sig. Den 27. juli 1914 rykkede den hertugelige generaldirektion i Primkenau for betalingen. Af en postanvisning blandt sagsakterne fremgår dog, at de $3.000 \mathrm{M}$ var blevet indbetalt allerede den 2 . juli 1914. Hermed var Aabenraa kreds' stridigheder med hertug Ernst Günther i kølvandet på baneanlæggene på Gråsten Godsdistrikt endeligt afsluttet. ${ }^{44}$

\section{Vurdering}

På baggrund af udredningen ovenfor af de langvarige sagsforløb synes der ikke at være taget hensyn til Ernst Günthers position som hertug og svoger til kejser Wilhelm II hos de involverede myndigheder i den preussiske offentlige administration. Den eneste gang under sagsforløbene, hvor der direkte toges hensyn til hertugen som svoger til kejseren, var i 1912, da kredsdagen i Aabenraa behandlede hertugens andragende for lukkede døre.

Men hertug Ernst Günther havde ressourcer til de langvarige trakasserier. Endvidere var hertugen i stand til at føre sagerne helt op til øverste niveau i den offentlige administration hos ministeren for offentlige arbejder, ligesom han i 1913 ikke veg tilbage fra at sagsøge Aabenraa kreds. Hertugen synes da at have haft en vis gennemslagskraft. Minister von Thielsen forordnede således i 1897 en ekstra besigtigelse af forholdene ved Østersø, og i 1911 besigtigede præsidenten 
for KED-Altona personligt forholdene ved Kastanieallé. Skulle præsidenten på den måde personligt tage sig af alle sager, hvor grundejere beklagede sig over problemer ved jernbaneanlæg som overskar private veje, kunne han formentlig ikke bestille andet. Dertil kommer, at Aabenraa kreds i 1898 ikke øjeblikkeligt skred til ekspropriation til trods for, at man havde fået tilladelse hertil. De forskellige myndigheder synes da trods alt at være gået lidt forsigtigt til værks $i$ jernbanesagerne med hertugen.

I sidste ende blev hertugens ønsker dog som oftest afvist og kun fulgt i de tilfælde, hvor ministeren, KED-Altona og Aabenraa kreds anerkendte konkrete sikkerhedsmæssige problemer og dermed en forpligtelse til at afbøde ulemper for Gråsten Godsdistrikt, som var opstået ved kredsbanens og statsbanens anlæg. Banernes linieføring gennem Stængerodde Skov og Østersø ændredes der således ikke ved på trods af, at hertugen fandt, at det ødelagde de landskabelige skønheder nær ved Gråsten Slot. Hertil kommer, at ministeren og regeringspræsidenten nok søgte at formidle en løsning mellem parterne. Men hverken ministeren eller regeringspræsidenten ville på noget tidspunkt banke KED-Altona eller Aabenraa kreds på plads for hertugen. At Aabenraa kreds i 1913 tilbød hertugen forlig i sagen om viadukten var af hensyn til kredsens svage økonomi og ikke af hensyn til hertug Ernst Günther.

Overordnet blev der altså ikke taget hensyn til hertug Ernst Günthers titel- og æresmæssige stilling. Hertug Ernst Günther havde nok ressourcer til at kaste sig ud i langvarige sagsforløb, ligesom de involverede niveauer $i$ den preussiske offentlige administration synes at være gået noget grundigere til værks end ellers. Men egentlige hensyn grundet Ernst Günthers stilling og svogerskabet til kejser Wilhelm II blev der altså i sidste ende ikke taget under sagsforløbene.

\section{KILDE- OG LITTERATURLISTE}

Litteratur:

Andersen, Poul: Graasten - et slot og et sogn, Gråsten 1986.

Hansen, L. H.: Aabenraa Amts Jernbaner 1899-1926, Aabenraa 1982.

Jacobsen, N.H.: Debatten om de nordslesvigske jernbaners udvikling 1864-1920.

I: Sonderjyske Årbøger 1976, s. 13-88.

Wilcke, Birger: $\notin$ Kringelbahn. Aabenraa Amts Jernbaner, Ølstykke 1982.
Aviser:

Apenrader Tageblatt, Aabenraa.

Hejmdal, Aabenraa.

Landsarkivet for Sonderjylland:

Aabenraa Amts Jernbaners arkiv (Aa.A.J.): 36/I:

36/IX: Acten der Kreisausschusses der Kreises Apenrade betreffend Verhandlungen mit Sr. Hoheit der Herzog Ernst 
Günther über die Ankauf der für Bahnbau erforderlichen Grund und Boden.

42a: Einweihung der Kleinbahn Apenrade-Gravenstein.

45a: Landespolezeilichen Prüfung des Kleinbahn Projektes Apenrade-Gravenstein.

78a: Fischbeck, Personal Akten der Station Fischbeck.

152: Privatanschluss der Actiengesellschaft Thonwaren Industrien, Gravenstein.

157: Klage Herzog Ernst Günthers wegen Herstellung einer fahrbaren Wegenünterführung.

166: 1899-1920. Sitzungen der Kreiseisenbahnkommission des Kreises Apenrade.

518: Bau einer Eisenbahn von Pattburg nach Sonderburg mit Abzweigung nach Tingleff.

538: Ankauf von Grund und Boden in Gravenstein.

540: Landespolezeiliche Abnahme der Staatsbahn Sonderburg-Pattburg/Tingleff.

\section{Rigsarkivet:}

Sonderjyske jernbanesager 1864-1920/ Königliche Eisenbahndirektion zu Altona (KED-Altona):

Kasse 8: Acten betreffend Bahnhof Gravenstein II: 01.01 1908-31.12 1913.

Acten betreffend Hafenbahn Gravenstein 31. juli 1912-.

Kasse 33: Acten betreffend Grunderwerb in der Gemarckung Gravenstein Gut.

Kasse 37: Landespolezeiliche Prüfung und Abnahme der Strecke Pattburg-TingleffSonderburg.

DSB, Baneafdelingen: Pk. 3354: Sønderjyllands Genforening.

\section{NOTER}

1. Wilcke, 1982, s. 19-42, s. 59f.

2. Aa.A.J. 36/I: 15 . oktober 1896.

3. Aa.A.J. 36/IX: 1. marts 1898.

4. Aa.A.J. 36/I: 15. oktober, 3. november og 17. december 1896. 9. januar 1897.

5. Aa.A.J. 45a: 29. og 30. juni og 1. juli 1897.

6. Aa.A.J. 45a: 27.0 g 28 . juni, 4 . september 1897. Andersen, 1986, s. 163ff.
7. Aa.A.J. 45a. 29. juli og 7. september 1897.

8. Aa.A.J. 45a: 16. og 29. oktober, 2., 13. og 17. november 1897.

9. Aa.A.J. 45a: 29. november, 2. og 3. december 1897.

10. Aa.A.J. 45a: 16. december 1897 og 3. februar 1898.

11. Aa.A.J. 36/IX: 16. og 21. februar 1898.

12. Aa.A.J. 36/IX: 25. februar, 1., 5., 15. , 20. og 21. marts 1898.

13. Aa.A.J. 36/IX: 6. og 9. april 1898.

14. Aa.A.J. 42a: Div. Akter.

15. Jacobsen, 1976, s35. Wilcke, 1982, s. $37 \mathrm{ff}$.

16. KED-Altona: 27 bd. 1: 14 . marts 1898.

17. KED-Altona: 27 bd. 1: 26 . marts, 3., 9 . og 19. april, 17. maj 1898.

18. Aa.A.J. 519: 13. september 1898.

19. KED-Altona: 33: 12. juni 1899. Aa.A.J. 519: 4. juli 1901.

20. Aa.A.J. 36/IX: 11. og 25. juni $1899+$ Traktatudkast.

21. Aa.A.J. 36/IX: 12. juni, 15. og 17. august, 8. september 1899.

22. Aa.A.J. 36/IX: 14. september 1899.

23. Aa.A.J. 36/IX: 1. december 1899, 10. april, 19. og 24. september 1900.

24. Aa.A.J. 36/IX + KED-Altona 33. 19. marts 1901.

25. Aa.A.J. 36/IX: 25./27. april, 9. og 14. maj 1901. KED-Altona 33: 8. juli 1901.

26. Aa.A.J. 36/IX/KED-Altona 33: 13. august, 5 . september, $12 . / 14$. oktober og 21. november 1901.

27. Aa.A.J. 540: 14. juni, 4., 6., 18., 25. og 29. juli, 12. og 14. august 1901.

28. KED-Altona 33: 9. januar 1902. Aa.A.J. 36/LX: 25. januar 1902.

29. KED-Altona 33: 25. og 30. januar, 10. og 14. februar 1902. Aa.A.J. 36/IX: 28. februar 1902.

30. Aa.A.J. 36/IX/KED-Altona 33: Diverse akter.

31. KED-Altona 8: Gravenstein II: Tegning af stedet 1911. Aa.A.J. 519: Fortegnelse over overskæringer mv. juni 1898.

32. Aa.A.J. 36/IX: 7./9. august 1906. KED-Altona 8: Gravenstein II: 8. august 1913.

33. Diverse køreplaner offentliggiort $i$ "Hejmdal + Wilcke, 1982, s. 85 og s. 103. Tallene er eksklusiv evt. rene godstog. 
34. KED-Altona 8: Gravenstein II: 28, juli 1911.

35. KED-Altona 8: Gravenstein II: 4. august 1911.

36. KED-Altona 8: Gravenstein II: 24. august, 26. september + tegninger og beregninger september 1911.

37. KED-Altona 8: Gravenstein II: 3. november 1911, 7. januar 1912, 19./22. maj, 3. og 7. juni 1913 + div. akter. Aa.A.J. 157: 7. oktober 1913.

38. Aa.A.J. 157: 19. februar, 26. marts 1912. Aa.A.J. 166: 6. marts 1912.

39. Aa.A.J 157: 31. juli, 2. august, 16 . og 21. oktober 1912. KED-Altona 8: Gra- venstein II: 8. august og 3. september 1913.

40. Aa.A.J. 157: 31. oktober og 13. december 1913

41. Aa.A.J. 157: 25. og 26. november 1913.

42. Aa.A.J. 157: 26. november (Uddrag af kredsudvalgsprotokollen), 29. november, 14. og 17. december 1913.

43. Aa.A.J. 166: 7. februar 1914. Aa.A.J. 157: 26. februar 1914. "Apenrader Tageblatt» og "Hejmdal« 27. februar 1914.

44. Aa.A.J. 157: 27. februar, 7. marts, 2. og 23. april, 2. og 27. juli 1914. 